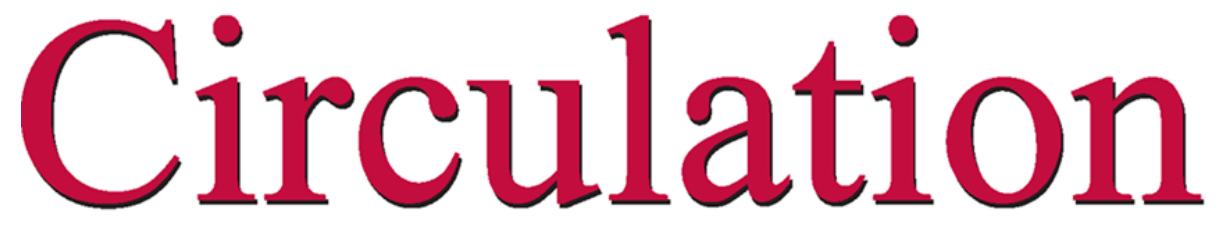

JOURNAL OF THE AMERICAN HEART ASSOCIATION
American Heart Association $_{\odot}$

Learn and Live

Association of elevated anti-sarcolemma, anti-idiotype antibody levels with the clinical and pathologic expression of chronic Chagas myocarditis

M Sadigursky, BF von Kreuter, PY Ling and CA Santos-Buch Circulation 1989;80;1269-1276

Circulation is published by the American Heart Association. 7272 Greenville Avenue, Dallas, TX 72514

Copyright $@ 1989$ American Heart Association. All rights reserved. Print ISSN: 0009-7322. Online ISSN: $1524-4539$

The online version of this article, along with updated information and services, is located on the World Wide Web at:

http://circ.ahajournals.org

Subscriptions: Information about subscribing to Circulation is online at http://circ.ahajournals.org/subscriptions/

Permissions: Permissions \& Rights Desk, Lippincott Williams \& Wilkins, a division of Wolters Kluwer Health, 351 West Camden Street, Baltimore, MD 21202-2436. Phone: 410-528-4050. Fax: 410-528-8550. E-mail: journalpermissions@1ww.com

Reprints: Information about reprints can be found online at http://www.lww.com/reprints 


\title{
Association of Elevated Anti-Sarcolemma, Anti-Idiotype Antibody Levels With the Clinical and Pathologic Expression of Chronic Chagas Myocarditis
}

\author{
Moyses Sadigursky, MD, Betsy F. von Kreuter, PhD, \\ Pei-Ying Ling, BS, and Charles A. Santos-Buch, MD
}

\begin{abstract}
Antibody $F\left(a b^{\prime}\right)_{2}$ fragments derived from the sera of four patients with histology-proven chronic Chagas myocarditis $\left[\mathbf{c F}\left(a^{\prime}\right)_{2}\right]$-complexed antibody $F\left(a b^{\prime}\right)_{2}$ fragments of children with acute Trypanosoma cruzi infection $\left[\mathbf{a F}\left(\mathbf{a b}^{\prime}\right)_{2}\right.$ ] in significantly higher molar ratios than those measured with $\mathrm{F}\left(\mathbf{a b}^{\prime}\right)_{2}$ antibody fragments of normal subjects $\left[\mathrm{nF}\left(\mathbf{a b}^{\prime}\right)_{2}\right]$ from nonendemic areas $(p<0.05)$. Anti-idiotype $\left[\mathrm{cF}\left(\mathrm{ab}^{\prime}\right)_{2} \times \mathrm{aF}\left(\mathrm{ab}^{\prime}\right)_{2}\right]$ immune-complex formation was significantly blunted by preabsorption of $\mathbf{c F}\left(\mathbf{a b}^{\prime}\right)_{2}$ with porcine heart atria sarcolemma (PAMs) immobilized on sepharose beads (inhibition, mean, 78.1 $\pm 2.4 \%, n=4) .\left[\mathrm{cF}\left(\mathrm{ab}^{\prime}\right)_{2} \times \mathrm{nF}\left(\mathrm{ab}^{\prime}\right)_{2}\right]$ immune-complex formation was also inhibited by pretreatment of $\mathrm{cF}\left(\mathbf{a b}^{\prime}\right)_{2}$ with PAMs (inhibition, mean, 48.7 $\pm 7.5 \%, n=4)$. The sera of three groups of subjects from a geographic zone endemic for $T$. cruzi infection in the northeast of Brazil were assayed for free and immune-complexed IgG anti-acute $T$. cruzi infection $F\left(a^{\prime}\right)_{2}$. The indexed levels of free IgG anti-idiotype antibody activity and levels of IgG anti-idiotype immune complexes $\left({ }^{\prime} C^{\prime}\right)$ were markedly elevated in hospitalized patients with severe, decompensated chronic Chagas myocarditis $(n=23)$, and their $I^{\prime} C^{\prime}$ indexes were significantly higher than those measured in asymptomatic seropositive subjects from a nearby endemic village of the northeast of Brazil (Moniz Ferreira, $n=92, p<0.001$ ) and in healthy seronegative villagers $(n=84, p<0.001)$. There exists a strong correlation between elevated IgG anti-sarcolemma, anti-idiotype activity levels and the clinical and pathologic expression of chronic Chagas myocarditis. (Circulation 1989;80:1269-1276)
\end{abstract}

$\mathrm{C}$

hronic Chagas myocarditis is the most frequent cause of congestive heart failure and sudden death in endemic areas of Central and South America. The etiologic agent of Chagas disease is the hemoflagellate, Trypanosoma cruzi, an obligatory intracellular protozoan. ${ }^{1}$ The autopsy of 35 mummies exhumed in the Chilean desert, dating between $470 \mathrm{BC}$ and $600 \mathrm{AD}$, revealed evidence of chronic Chagas disease, and this study gave a strong indication that adaptation of the blood-sucking Triatomine (Reduviid) insect vector

From the Centro de Pesquisa Gonzalo Moniz (M.S.), Salvador, Bahia, Brazil, and the Department of Pathology (B.F.v.K., P.-Y.L., C.A.S.-B.), Cornell University Medical College, New York, New York.

Supported by the Muscular Dystrophy Association, the National Institutes of Health (HL-34221), and the UNDP/World Bank/WHO Special Programme for Research and Training in Tropical Diseases.

Address for correspondence: Dr. Charles A. Santos-Buch, Department of Pathology, Cornell University Medical College, 1300 York Avenue, New York, NY 10021.

Received June 9, 1988; revision accepted June 20, 1989. to dwellings had occurred since pre-Columbian times, documenting their persistent aggressiveness for human hosts. ${ }^{2}$ After the Triatomine attack, metacyclic trypomastigotes deposited with the feces after the blood meal may contaminate the wound or mucosal membranes, and a subsequent parasitemia may ensue in human hosts. In an undetermined number of $T$. cruzi seropositive, chronically infected subjects with varying degrees of immunosuppression, ${ }^{3-5}$ a severe and progressive myocarditis may develop months or years later.$^{6}$ Chronic Chagas myocarditis is frequently associated with increased levels of IgG antibody against myocardial sarcolemma epitopes. ${ }^{7}$ Moreover, an anti-T. cruzi membrane antibody that is cross reactive with a myocardial cell sarcoplasmic reticulum antigen and is also expressed in the sarcolemma has been identified. ${ }^{7-9}$ However, the pathogenic potential of this and other anti-heart and anti-laminin antibodies shown in subjects with chronic Chagas myocarditis is not fully understood. ${ }^{10,11}$ 
Experimental observations have shown that $T$. cruzi parasitemia is often followed by myotropic infection of host Type I striated muscle fibers, including the heart. ${ }^{2}$ Recent investigation has shown that myotropic host-cell recognition is promoted by the chemoaffinity of $T$. cruzi attachment molecules to receptors of the muscle fiber and that these attachment sites are complementary and antigenic. ${ }^{13}$ In a recent report we showed that $T$. cruzi plasma-membrane attachment sites interacted with heart muscle sarcolemma muscarinic cholinergic and $\beta$-adrenergic receptors in the recognition and adhesion phenomenon. ${ }^{14}$ Furthermore, an IgG antibody from patients with Chagas disease has been shown to bind $\beta$-adrenergic receptors of the myocardium and to modulate their adenylyl cyclase activity. ${ }^{15}$ Moreover, when monospecific $\mathbf{F}\left(\mathrm{ab}^{\prime}\right)_{2}$ antibody against $T$. cruzi surface antigens was allowed to react with monospecific $\mathrm{F}\left(\mathrm{ab}^{\prime}\right)_{2}$ antibody against muscle surface antigens, immune complexes were formed in a concentration-dependent fashion similar to that seen with anti-idiotype immune reactions. ${ }^{13}$

The hypothesis that anti-idiotype antibodies may be pathogenic has been raised in connection with idiopathic thrombocytopenia purpura, ${ }^{16}$ insulindependent diabetes mellitus, ${ }^{17}$ myasthenia gravis, ${ }^{18}$ polymyositis-dermatomyositis, ${ }^{19}$ and Kawasaki's disease ${ }^{20}$ Moreover, there are several observations suggesting a link between viral infection, antiidiotype antibodies, and autoimmune diseases, ${ }^{21}$ including postviral myocarditis. ${ }^{22}$ The data in hand, therefore, suggested that an IgG anti-idiotype antibody against the primary anti- $T$. cruzi antibody may also be reactive to the antigenic, complementary recognition receptors of the sarcolemma, thereby inflicting myocarditis. ${ }^{13}$

We sought to investigate the possible association of IgG anti-idiotype antibody activity (anti-Id) and severe chronic Chagas myocarditis. To accomplish this we showed first that the antigen-binding fragment of the IgG molecule $\left[\mathrm{F}\left(\mathrm{ab}^{\prime}\right)_{2}\right]$ of four highly selected, $T$. cruzi-seropositive adult patients with histology-proven myocarditis complexed to the antigen-binding site of IgG antibodies obtained from children with acute $T$. cruzi parasitemia, a pooled source of primary antibody. We also compared serum levels of anti-Id and anti-Id-immune complexes in 92 seropositive but asymptomatic subjects of the village of Moniz Ferreira of the State of Bahia in the northeast of Brazil, which was endemic for $T$. cruzi infection, with 23 seropositive patients with severe chronic myocarditis and congestive heart failure hospitalized nearby in the capital city of Salvador. A group of 84 seronegative, apparently healthy villagers served as controls.

\section{T. Cruzi Serology}

Methods

Seropositive sera were defined when hemagglutination, complement fixation, and immunofluorescent tests against $T$. cruzi antigens proved positive on two subsequent 1-month bleedings. Seronegative sera were within the normal limits of all three tests.

\section{T. Cruzi Parasitemia}

This was determined by direct examination of the peripheral blood of infected children on Giemsastained smears.

\section{Antigens}

Acute T. cruzi infection $F\left(a b^{\prime}\right)_{2}\left[a F\left(a b^{\prime}\right)_{2}\right]$. One half- to $1-\mathrm{ml}$ aliquots of sera from 29 children, 10 months to 8 years old, with acute $T$. cruzi parasitemia were pooled. The clinical history indicated that the duration of infection was not more than 60 days since onset. The $F\left(a b^{\prime}\right)_{2}$ fragment was prepared from pepsin digests of IgG from the filtered, dilipidated serum by published technique. ${ }^{13}$ After chromatography, undigested IgG and Fc fragment contaminants were removed by protein A Sepharose 4B (Pharmacia, Piscataway, New Jersey) treatment and stored frozen at $-20^{\circ} \mathrm{C}$ until used.

Nonendemic, normal $F\left(a b^{\prime}\right)_{2}\left[n F\left(a b^{\prime}\right)_{2}\right]$. Nonendemic, normal, healthy nontransfused, US male donors were the source of affinity-purified $F\left(a^{\prime}\right)_{2}$ fragments, purchased from Pel-Freeze (Rogers, Arkansas) and stored frozen at $-20^{\circ} \mathrm{C}$ until used.

\section{Test Antibodies}

$F\left(a b^{\prime}\right)_{2}$ of histology-proven chronic Chagas myocarditis patients $\left[c F\left(a b^{\prime}\right)_{2}\right]$. The sera of three male patients, 32-45 years old, with endomyocardial biopsy-proven chronic Chagas myocarditis were obtained from the Cardiology Service of the Ramos Mejia Hospital, Buenos Aires, Argentina (Dr. Mauricio B. Rosenbaum). The serum of one patient from the borough of Queens, New York, a 24year-old male immigrant from Honduras, who received a cardiac transplant for chronic Chagas myocarditis, was also drawn for the study. ${ }^{24}$ The clinical diagnosis of chronic Chagas myocarditis was based on 1) seropositive tests for $T$. cruzi infection; 2) cardiomegaly by chest radiograph; and 3) electrocardiographic studies showing bradycardia, right bundle branch block, or both, plus or without left anterior hemiblock, with severe intraventricular conduction abnormalities, SS-T changes, or both, plus or without varying degrees of heart block. The histopathologic diagnosis was based on the identification of a florid lymphoreticular interstitial exudate, occasional myofiber necrosis, and varying degrees of connective tissue replacement. Pseudocysts with $T$. cruzi amastigotes were not found. The $F\left(a b^{\prime}\right)_{2}$ fragments of the IgG of each of the four patients were prepared as described for the pool of acute $T$. cruzi infection $\mathrm{F}\left(\mathrm{ab}^{\prime}\right)_{2}$.

Reactive IgG of sera from the ambulatory villagers of Moniz Ferreira (Bahia, Brazil). Moniz Ferreira is a village of 2,500 inhabitants of the state of Bahia, about $80 \mathrm{~km}$ west of the capital city, Salvador, in northeastern Brazil. Public health seroepi- 
demiologic surveys had shown that the village was endemic for $T$. cruzi infection and that many homes were infested by the vector, the Triatoma (Reduviid) insect. The sera of 84 apparently healthy, seronegative subjects, 38 men and 46 women, 1644 years old (mean age, 29 years) were obtained for the study. Sera of 92 , age- and sex-matched seropositive asymptomatic villagers were drawn. All samples were coded and stored frozen at $-20^{\circ} \mathrm{C}$ until used.

Reactive IgG of chronic Chagas myocarditis sera from hospitalized patients diagnosed by clinical criteria. The sera of 23 patients, residents of nearby endemic zones who were hospitalized in the Edgar dos Santos Hospital in Salvador for congestive heart failure due to severe chronic Chagas myocarditis, were coded and stored frozen $\left(-20^{\circ} \mathrm{C}\right)$ before use. The criteria for the clinical diagnosis of chronic Chagas myocarditis were based on the same criteria as those of the histology-proven myocarditis group. Fourteen men and nine women, 27-52 years old (mean age, 42 years) were culled for the study.

$\left({ }^{125} I\right)$-acute T. cruzi infection $F\left(a b^{\prime}\right)_{2} \times$ chronic Chagas myocarditis $F\left(a b^{\prime}\right)_{2}$ complex formation. Private specificity was measured by complexing acute $T$. cruzi infection $\left({ }^{125} \mathrm{I}\right)-\mathrm{F}\left(\mathrm{ab}^{\prime}\right)_{2}\left[\mathrm{aF}\left(\mathrm{ab}^{\prime}\right)_{2}\right]$ and $\mathrm{cF}\left(\mathrm{ab}^{\prime}\right)_{2}$ fragments from patients with histology-proven chronic Chagas myocarditis in duplicate in $1.5-\mathrm{ml}$ Eppendorf microfuge tubes (VWR, South Plainfield, New Jersey). Measurement of public specificity consisted of complexes formed by nonendemic, normal $\left({ }^{125} \mathrm{I}\right)-\mathrm{F}\left(\mathrm{ab}^{\prime}\right)_{2}\left[n \mathrm{~F}\left(\mathrm{ab}^{\prime}\right)_{2}\right]$ obtained from Calbiochem, La Jolla, California. $\mathrm{F}\left(\mathrm{ab}^{\prime}\right)_{2}$ iodination was done by solid-phase glucose oxidase and lactoperoxidase treatment (Enzymobead radioiodination reagent, BioRad, Rockville Centre, New York), followed with $\mathrm{Na}^{125} \mathrm{I}$ (ICN, Irvine, California). Unbound $\mathrm{Na}^{125} \mathrm{I}$ was removed by exhaustive dialysis at $4^{\circ}$ C..$^{13}$ Care was taken to maintain specific radioactivity at levels of $5,500-8,000 \mathrm{cpm} / \mathrm{pmol}$ $\mathrm{F}\left(\mathrm{ab}^{\prime}\right)_{2}$. Immune-complex formation was done by the addition of exactly $50 \mathrm{pmol}$ of the radiolabeled $\mathrm{aF}\left(\mathrm{ab}^{\prime}\right)_{2}$ to $100-122$ pmol of the test $\mathrm{cF}\left(\mathrm{ab}^{\prime}\right)_{2}$, bringing the final reaction volume to $500 \mu \mathrm{l}$ in phosphatebuffered saline (PBS). The tubes were mixed and incubated at $37^{\circ} \mathrm{C}$ for 2 hours, followed by an overnight incubation at $4^{\circ} \mathrm{C}$. The immune complexes were precipitated by polyethylene-glycol6000 (PEG) treatment. ${ }^{13}$ The background radioactivity produced by the radiolabeled $\mathrm{aF}\left(\mathrm{ab}^{\prime}\right)_{2}$ fragments alone, which remained after completion of the procedure, consistently ranged $3-5 \%$ of the total applied (mean, $4.2 \%$ ).

Inhibition of immune complex formation by preabsorption of $\mathrm{cF}\left(a b^{\prime}\right)_{2}$ with porcine heart atria sarcolemma. This was done by preincubation of 100-122 pmol of $\mathrm{cF}\left(\mathrm{ab}^{\prime}\right)_{2}$ antibody fragments with porcine heart atria sarcolemma (PAMs) immobilized on sepharose and previously prepared from fresh tissue by our published technique. ${ }^{14}$ Sepharose $\mathrm{CNBr}$-coupled PAMs were prepared according to the technique recommended by the manufacturer (Pharmacia). Two hundred $\mu$ l of a $50 \%$ ( $\mathrm{vol} / \mathrm{vol}$ ) PAMs on beads in a PBS suspension was used for absorption in each tube. Incubation for absorption was 2 hours at $37^{\circ} \mathrm{C}$ followed by overnight treatment at $4^{\circ} \mathrm{C}$. After centrifugation at $15,000 \mathrm{~g}$ for 1 hour at $4^{\circ} \mathrm{C}$, immune-complex formation with radiolabeled $\mathrm{aF}\left(\mathrm{ab}^{\prime}\right)_{2}$ and $\mathrm{cF}\left(\mathrm{ab}^{\prime}\right)_{2}$ or $\mathrm{nF}\left(\mathrm{ab}^{\prime}\right)_{2}$ was measured in an aliquot of the supernatant.

Total specific IgG anti-acute T. cruzi infection $F\left(a b^{\prime}\right)_{2}$. All tests with population sera and with sera of patients with the clinical diagnosis of chronic Chagas myocarditis were done in duplicate without previous knowledge of their origin. The enzymelinked immunosorbent assay (ELISA) was used to identify bound IgG. ${ }^{25}$ The sera were previously acidified with $0.15 \mathrm{M} \mathrm{NaCl}$ in $0.01 \mathrm{M}$ glycine-HCL buffer $(\mathrm{pH} 2.5)$ in a final 1:40 dilution to dissolve immune complexes. The acidified $(\mathrm{pH} 3)$ test sera were next diluted in microtiter wells (Falcon, Oxnard, California) previously coated with $\mathrm{F}\left(\mathrm{ab}^{\prime}\right)_{2}$ antigens with an equal volume $(100 \mu \mathrm{l})$ of $0.15 \mathrm{M}$ $\mathrm{NaCl}$ in $0.06 \mathrm{M}$ phosphate buffer, $\mathrm{pH} 7.4$, with $5 \%$ (vol/vol) fetal bovine serum (FBS) (Hyclone, Logan, Utah) and $0.05 \%$ (vol/vol) Tween 20 (Sigma Chemical, St. Louis, Missouri). This resulted in conversion of the $\mathrm{pH}$ of the reaction mixture to 7.3 and allowed the nascent antibodies to react with the excess solid phase $\mathrm{aF}\left(\mathrm{ab}^{\prime}\right)_{2}$ antigens (1 hour at $\left.37^{\circ} \mathrm{C}\right)$. The wells were coated with $0.5 \mu \mathrm{g} \mathrm{aF}\left(\mathrm{ab}^{\prime}\right)_{2}$ fragments in carbonate buffer $\mathrm{pH} 9.6$ and $0.02 \%$ (wt/vol) $\mathrm{NaN}_{3}$ according to published technique. ${ }^{25}$ Bound $\mathrm{IgG}$ was indexed with alkaline phosphataseconjugated affinity-purified rabbit $\mathrm{F}\left(\mathrm{ab}^{\prime}\right)_{2}$ antihuman Fc fragment (Pel-Freeze, Rogers, Arkansas) at an appropriate dilution. The subsequent washes and substrate incubations followed published technique. ${ }^{25}$ The plates were read in a Titertek Multiscan Plus spectrophotometer (Flow Laboratories, McLean, Virginia), at an optical density (OD) of $405 \mathrm{~nm}$. The OD obtained with nonendemic normal $\mathrm{F}\left(\mathrm{ab}^{\prime}\right)_{2}$ ranged $14-19 \%$ in all tests $(n=199)$. The corrected specific total antibody activity was tabulated after subtraction of the OD obtained with nonendemic, normal human $\mathrm{F}\left(\mathrm{ab}^{\prime}\right)_{2}$ in duplicate parallel tests.

Free IgG anti-idiotype activity and calculation of anti-idiotype immune complexes. This was done in a similar procedure at physiologic $\mathrm{pH}(7.4)$ by omitting the acid treatment. Levels of anti-idiotype immune complexes $\left(I^{\prime}\right)$ were indexed by calculating the difference between the optical density of total and free specific IgG anti-T. cruzi infection $\mathrm{F}\left(\mathrm{ab}^{\prime}\right)_{2}$.

Metacyclic T. cruzi trypomastigotes. Brazilstrain metacyclic trypomastigotes were harvested in the log phase of growth after Giemsa-stained counts showed that more than $90 \%$ of the flagellates were in the tissue-infective metacyclic form. ${ }^{26}$ 
Table 1. Myocarditis Immune-Complex Formation by Antigen-Binding Fragments of Primary Antibody and Inhibition of ImmuneComplex Formation by Sarcolemma

\begin{tabular}{|c|c|c|c|c|c|}
\hline $\begin{array}{l}\text { Myocarditis immune-co } \\
\text { Acute parasitemia- } \\
\left({ }^{125} \mathrm{I}\right)-\mathrm{aF}\left(\mathrm{ab}^{\prime}\right)_{2}(\mathrm{pmol})\end{array}$ & \multicolumn{2}{|c|}{$\begin{array}{c}\mathrm{F}\left(\mathrm{ab}^{\prime}\right)_{2} \text { added } \\
(\mathrm{pmol})\end{array}$} & $\begin{array}{c}\text { Complexed } \\
\text { acute parasitemia- } \\
\left({ }^{125} \mathrm{I}\right)-\mathrm{aF}\left(\mathrm{ab}^{\prime}\right)_{2} \\
(\mathrm{pmol})\end{array}$ & $\begin{array}{c}\text { Correction } \\
(\mathrm{pmol})\end{array}$ & $\begin{array}{l}\text { Molar ratio } \\
\left(\mathrm{d} / \mathrm{b} \times 10^{-3}\right)\end{array}$ \\
\hline \multirow[t]{3}{*}{2.5} & \multirow{2}{*}{\multicolumn{2}{|c|}{ none }} & Background & NA & NA \\
\hline & & & $0.101 \pm 0.006$ & & \\
\hline & \multicolumn{2}{|c|}{ Normal } & & $-(1)$ & \\
\hline \multirow[t]{2}{*}{50} & \multicolumn{2}{|c|}{120} & $1.794 \pm 0.120$ & $1.693 \pm 0.12$ & $14.1 \pm 1.0^{*}$ \\
\hline & \multicolumn{2}{|c|}{ Chronic myocarditis } & & ${ }^{-}[(1)+(2)]^{\dagger}$ & \\
\hline 50 & $\overline{\mathrm{UM}}$ & 120 & $6.05 \pm 0.73$ & $4.25 \pm 0.05$ & $35.4 \pm 0.45$ \\
\hline 50 & $\mathrm{PP}_{3}$ & 122 & $6.48 \pm 0.17$ & $4.68 \pm 0.12$ & $38.4 \pm 1.00$ \\
\hline 50 & 10 & 120 & $5.85 \pm 0.49$ & $4.05 \pm 0.34$ & $33.8 \pm 2.84$ \\
\hline 50 & 14 & 100 & $5.68 \pm 0.19$ & $3.89 \pm 0.13$ & $38.9 \pm 1.32$ \\
\hline
\end{tabular}

Inhibition of immune-complex formation

\begin{tabular}{lcccc}
$\begin{array}{l}\text { Chronic myocarditis- } \\
\mathrm{cF}\left(\mathrm{ab}^{\prime}\right)_{2} \text { absorbed with } \\
\text { sarcolemma (pmol } \\
\text { before absorption) }\end{array}$ & $\begin{array}{c}\text { Complexed } \\
\text { acute parasitemia- } \\
\left(\begin{array}{l}125 \mathrm{I})-\mathrm{aF}\left(\mathrm{ab}^{\prime}\right)_{2} \\
(\mathrm{pmol})\end{array}\right.\end{array}$ & $\begin{array}{c}\text { Molar ratio } \\
\text { absorbed } \\
\left(\mathrm{b} / \mathrm{a} \times 10^{-3}\right)\end{array}$ & $\begin{array}{c}6.54 \pm 0.29^{*} \\
\text { Inhibition }(\%)\end{array}$ \\
\hline $\mathrm{UM}$ & 120 & $0.79 \pm 0.04$ & $8.11 \pm 0.32^{*}$ & 78.9 \\
$\mathrm{PP}_{3}$ & 122 & $0.99 \pm 0.04$ & $8.42 \pm 0.98^{*}$ & 75.1 \\
10 & 120 & $1.01 \pm 0.12$ & $8.99 \pm 0.12^{*}$ & 76.9 \\
14 & 100 & $0.90 \pm 0.01$ & $8.02 \pm 0.43$ & $78.1 \pm 2.4$ \\
\hline
\end{tabular}

$\mathrm{aF}\left(\mathrm{ab}^{\prime}\right)_{2}$, acute $T$. cruzi parasitemia antibody fragment; $\mathrm{cF}\left(\mathrm{ab}^{\prime}\right)_{2}$, chronic Chagas myocarditis antibody fragment; \% Inhibition $=100-($ Molar ratio absorbed/Molar ratio not absorbed $) \times 100$.

${ }^{*} p<0.05$ vs. not absorbed.

${ }^{\dagger}$ Private specificity calculated by subtracting background and public specificity.

Statistical analysis. The results were compared by Student's $t$ test and Fisher's exact test. ${ }^{27} \mathrm{~A} p$ value of less than 0.05 was assigned significance.

\section{Results}

When the $\mathrm{F}\left(\mathrm{ab}^{\prime}\right)_{2}$ fragments of four histologyproven myocarditis, $T$. cruzi seropositive patients were allowed to react with the radiolabeled $\mathrm{F}\left(\mathrm{ab}^{\prime}\right)_{2}$ fragments of a pool of sera of children with acute $T$. cruzi parasitemia, $33.8-38.9 \mathrm{mM}$ radiolabeled acute $T$. cruzi infection $\mathrm{F}\left(\mathrm{ab}^{\prime}\right)_{2} / \mathrm{mol}$ chronic Chagas myocarditis $\mathrm{F}\left(\mathrm{ab}^{\prime}\right)_{2}$ were specifically complexed [mean, $\left.36.6 \pm 1.4 \mathrm{mM} \mathrm{aF}\left(\mathrm{ab}^{\prime}\right)_{2} / \mathrm{M} \mathrm{cF}\left(\mathrm{ab}^{\prime}\right)_{2}, n=4\right]$ (Table 1). These molar ratios were 2.6 -fold higher than those obtained when normal, nonendemic antibody $\mathrm{F}\left(\mathrm{ab}^{\prime}\right)_{2}$ fragments were used against $\left({ }^{125} \mathrm{I}\right)-\mathrm{aF}\left(\mathrm{ab}^{\prime}\right)_{2}[(14.1 \pm 1.0$ $\mathrm{mM}$ radiolabeled $\mathrm{aF}\left(\mathrm{ab}^{\prime}\right)_{2} / \mathrm{mol}$ normal $\mathrm{F}\left(\mathrm{ab}^{\prime}\right)_{2}$; $p<0.05)]$. When $\mathrm{cF}\left(\mathrm{ab}^{\prime}\right)_{2}$ fragments of the $\mathrm{IgG}$ of the four histology-proven myocarditis subjects were allowed to react with the radiolabeled $\mathrm{F}\left(\mathrm{ab}^{\prime}\right)_{2}$ fragments of normal, nonendemic IgG, 5.85-7.99 mM radiolabeled normal $\mathrm{F}\left(\mathrm{ab}^{\prime}\right)_{2} / \mathrm{mol}$ chronic Chagas myocarditis $\mathrm{F}\left(\mathrm{ab}^{\prime}\right)_{2}$ were specifically complexed [mean, $7.35 \pm 0.43 \mathrm{mM} \mathrm{F}\left(\mathrm{ab}^{\prime}\right)_{2} / \mathrm{mol} \mathrm{cF}\left(\mathrm{ab}^{\prime}\right)_{2}$ ] (public specificity) (Table 2). These molar ratios were 5.0 -fold less than those obtained when radiolabeled acute $T$. cruzi infection $\mathrm{F}\left(\mathrm{ab}^{\prime}\right)_{2}$ fragments were used $(p<0.05)$. These results showed that the antigen-binding site of IgG molecules of the sera of patients with chronic Chagas myocarditis specifically complexed the antigen-binding site of IgG molecules of the sera of children with acute $T$. cruzi parasitemia, the source of primary antibody. When the $\mathrm{cF}\left(\mathrm{ab}^{\prime}\right)_{2}$ of patients with histology-proven chronic myocarditis was absorbed against PAMs, immune-complex formation with $\left({ }^{125} \mathrm{I}\right)-\mathrm{nF}\left(\mathrm{ab}^{\prime}\right)_{2}$ (public specificity) was blunted (37.3-57.3\% inhibition) (Table 2). When the chronic myocarditis $\mathrm{cF}\left(\mathrm{ab}^{\prime}\right)_{2}$ was absorbed against PAMs, immune-complex formation with $\left({ }^{125} \mathrm{I}\right)$ $\mathrm{aF}\left(\mathrm{ab}^{\prime}\right)_{2}$ (private specificity) was also significantly inhibited (75.1-81.5\% inhibition) (Table 1). These results indicated to us that chronic Chagas myocarditis patients had circulating anti-idiotype antibody with private and public specificity against 1) antibodies raised in children with acute $T$. cruzi parasitemia and 2) antibodies of healthy, nontransfused male donors of a nonendemic zone of North America. Moreover, a large proportion of the chronic Chagas myocarditis anti-idiotype antibody was also reactive against epitopes of the myocardial cell plasma membranes (Tables 1 and 2). With these data in hand, what remained was to show whether there were significant differences in levels of antiidiotype antibody activity in large numbers of subjects from an endemic zone for $T$. cruzi infections. 
TABLE 2. Myocarditis Immune-Complex Formation by Antigen Binding Fragments of Normal Antibody and Inhibition of ImmuneComplex Formation by Sarcolemma

Myocarditis immune-complex formation

\begin{tabular}{|c|c|c|c|c|c|}
\hline $\begin{array}{l}\text { Normal fragments- } \\
\left({ }^{125} \mathrm{I}\right)-\mathrm{nF}\left(\mathrm{ab}^{\prime}\right)_{2}(\mathrm{pmol})\end{array}$ & \multicolumn{2}{|c|}{$\mathrm{F}\left(\mathrm{ab}^{\prime}\right)_{2}$ added $(\mathrm{pmol})$} & $\begin{array}{l}\text { Complexed } \\
\text { normal- } \\
\left({ }^{125} \mathrm{I}\right)- \\
\mathrm{nF}\left(\mathrm{ab}^{\prime}\right)_{2} \\
(\mathrm{pmol})\end{array}$ & $\begin{array}{l}\text { Correction } \\
(\mathrm{pmol})\end{array}$ & $\begin{array}{l}\text { Molar ratio } \\
\left(d / b \times 10^{-3}\right)\end{array}$ \\
\hline \multirow[t]{2}{*}{50} & \multicolumn{2}{|c|}{ None } & $0.143 \pm 0.008$ & NA & NA \\
\hline & \multicolumn{2}{|c|}{ Chronic myocarditis } & & & \\
\hline 50 & UM & 120 & $0.85 \pm 0.04$ & $0.70 \pm 0.03$ & $5.85 \pm 0.29$ \\
\hline 50 & $\mathrm{PP}_{3}$ & 122 & $1.11 \pm 0.00$ & $0.97 \pm 0.00$ & $7.91 \pm 0.03$ \\
\hline 50 & 10 & 120 & $1.10 \pm 0.10$ & $0.96 \pm 0.09$ & $7.99 \pm 0.74$ \\
\hline \multirow[t]{2}{*}{50} & 14 & 100 & $0.91 \pm 0.08$ & $0.77 \pm 0.07$ & $7.66 \pm 0.67$ \\
\hline & & & & & $7.35 \pm 0.43$ \\
\hline
\end{tabular}

\begin{tabular}{|c|c|c|c|c|c|}
\hline \multicolumn{6}{|c|}{ Inhibition of immune-complex formation } \\
\hline \multicolumn{2}{|c|}{$\begin{array}{c}\text { Chronic myocarditis- } \\
\mathrm{cF}\left(\mathrm{ab}^{\prime}\right)_{2} \text { absorbed with } \\
\text { sarcolemma (pmol before } \\
\text { absorption) }\end{array}$} & \multirow{2}{*}{$\begin{array}{c}\begin{array}{c}\text { Complexed normal- } \\
\left({ }^{125} \mathrm{I}\right)-\mathrm{nF}\left(\mathrm{ab}^{\prime}\right)_{2}(\mathrm{pmol})\end{array} \\
0.58 \pm 0.02\end{array}$} & \multirow{2}{*}{$\begin{array}{r}\begin{array}{r}\text { Correction } \\
-(1)(\mathrm{pmol})\end{array} \\
0.44 \pm 0.01\end{array}$} & \multirow{2}{*}{$\begin{array}{c}\begin{array}{c}\text { Molar ratio } \\
\text { absorbed } \\
\left(\mathrm{c} / \mathrm{a} \times 10^{-3}\right)\end{array} \\
3.67 \pm 0.11\end{array}$} & \multirow{2}{*}{$\frac{\text { Inhibition }(\%)}{37.3}$} \\
\hline UM & 120 & & & & \\
\hline $\mathrm{PP}_{3}$ & 122 & $0.58 \pm 0.00$ & $0.41 \pm 0.00$ & $3.38 \pm 0.03$ & 57.3 \\
\hline 10 & 120 & $0.59 \pm 0.02$ & $0.45 \pm 0.01$ & $3.74 \pm 0.10$ & 53.2 \\
\hline \multirow[t]{2}{*}{14} & 100 & $0.55 \pm 0.03$ & $0.41 \pm 0.02$ & $4.06 \pm 0.23$ & 47.0 \\
\hline & & & & $3.71 \pm 0.12$ & $48.7 \pm 7.5$ \\
\hline
\end{tabular}

$\mathrm{nF}\left(\mathrm{ab}^{\prime}\right)_{2}$, antibody fragment from normal sera; $\mathrm{cF}\left(\mathrm{ab}^{\prime}\right)_{2}$, antibody fragment from chronic Chagas myocarditis sera; \% Inhibition $=100-($ Molar ratio absorbed/Molar ratio not absorbed $) \times 100$.

The conditions for assay of Moniz Ferriera villager anti-idiotype antibody activity described in this report allowed for the indexing of total and free IgG anti-acute $T$. cruzi infection $\mathrm{F}\left(\mathrm{ab}^{\prime}\right)_{2}$ activity of large numbers of test sera. The specificity of the assay for anti-idiotype antibody was further established by showing that preabsorption of the abnormal sera with live, tissue-infective, metacyclic trypomastigotes $\left(5 \times 10^{6} / \mathrm{ml}\right)$ failed to inhibit the reaction of IgG anti-acute T. cruzi $\mathrm{F}\left(\mathrm{ab}^{\prime}\right)_{2}$ by more than $15 \%$ (Table 3).

When the cutoff normal value was calculated from the median optical density plus 2 SEM of seronegative Moniz Ferreira villagers, 20 of 23 $(87.0 \%)$ hospitalized patients with severe chronic

Table 3. Total Specific IgG Anti-Acute T. cruzi Infection $\mathbf{F}\left(\mathbf{a b}^{\prime}\right)_{2}$ Activity

\begin{tabular}{lccc}
\hline & \multicolumn{3}{c}{${\text { Abnormal* } \mathrm{OD}_{405}}$} \\
\cline { 2 - 4 } Subjects & $>0.360(\%)$ & $<0.360$ & $n$ \\
\hline Chronic Chagas myocarditis $\dagger$ & $20(87.0)$ & 3 & 23 \\
Seropositive and asymptomatic & $30(32.6)$ & 62 & 92 \\
Seronegative and healthy & $4(4.8) \ddagger$ & 80 & 84 \\
\hline
\end{tabular}

$p<0.001$ by Fisher's exact test.

*The median optical density value plus two times the SEM of seronegative Moniz Ferreira subjects was used as the cutoff normal value $(>0.360)$.

$\dagger$ After treatment with $5 \times 10^{8}$ flagellates/ml of live metacyclic trypomastigotes to absorb primary IgG anti- $T$. cruzi surface antigen, the optical density was reduced $10-15 \%$.

$\ddagger$ These four subjects remain seronegative and asymptomatic to date.
Chagas myocarditis showed abnormal elevated levels of IgG anti-acute $T$. cruzi infection $\mathrm{F}\left(\mathrm{ab}^{\prime}\right)_{2}$. In contrast, only four of $84(4.8 \%)$ apparently healthy, seronegative Moniz Ferreira villagers had values above the normal calculated cutoff, and this difference was statistically significant by two-tailed Fisher's exact test $(p<0.001)$. Thirty of $92(32.6 \%)$ seropositive but asymptomatic Moniz Ferreira villagers showed abnormal, elevated IgG anti-acute $T$. cruzi infection $\mathrm{F}\left(\mathrm{ab}^{\prime}\right)_{2}$ activity (Table 3 ). We believe that subclinical cases are probably included in the latter group because no sophisticated cardiology was done to identify symptomless myocarditis in the seroepidemiologic survey conducted by the state of Bahia. Nevertheless, when Fisher's exact test was used, statistically significant differences were again found between the hospitalized group of patients with congestive heart failure and severe chronic Chagas myocarditis and the asymptomatic group of seropositive villagers $(0.02>p>0.01)$.

The distribution of free- and complexed-IgG antiacute $T$. cruzi infection $\mathrm{F}\left(\mathrm{ab}^{\prime}\right)_{2}$ was compared among seronegative and seropositive asymptomatic Moniz Ferreira villagers and hospitalized chronic Chagas myocarditis patients with congestive heart failure. Figure 1 plots the free IgG anti-Id and immunecomplexed IgG anti-Id (IC') for each subject. When the $t$ distribution of $\mathrm{IC}^{\prime}$ of the three groups is compared, each is significantly statistically different from the other $(p<0.001)$. It can be appreciated from Figure 1 that the median values of free and 


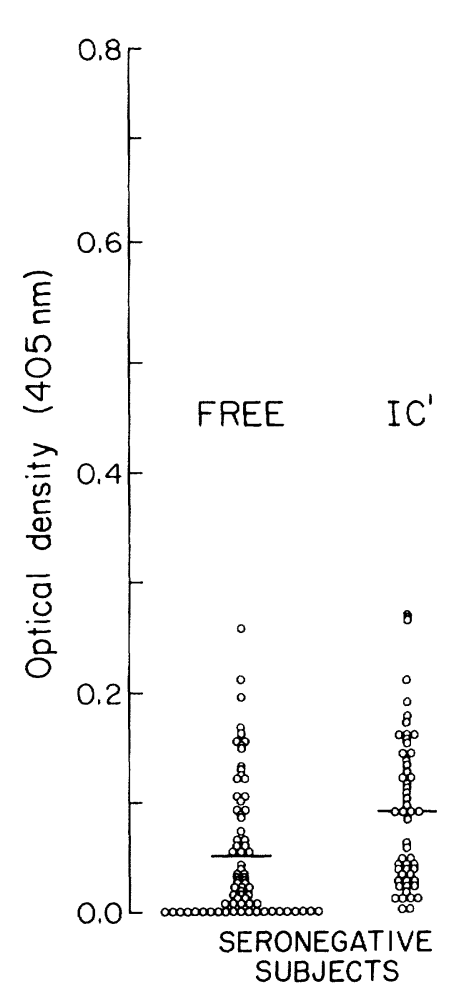

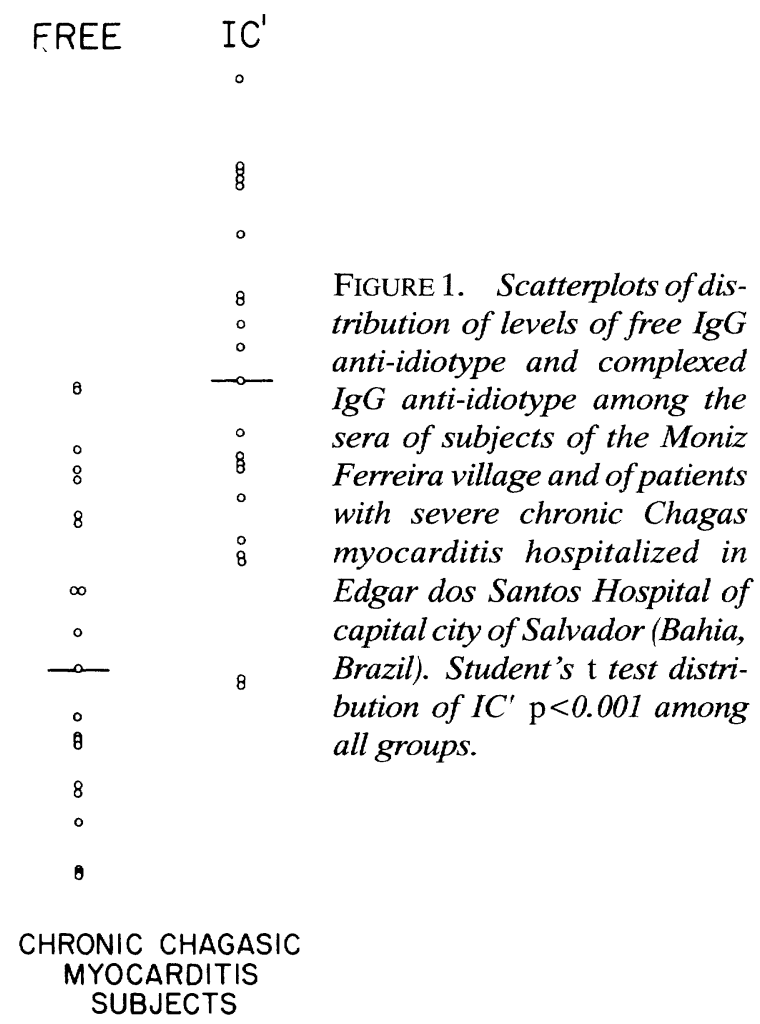

complexed-IgG anti-Id measured for the hospitalized patients with chronic Chagas myocarditis are markedly elevated above the seronegative villagers of Moniz Ferreira. It is particularly noteworthy that, even though values overlap among the seropositive subjects, IgG anti-Id immune complexes were highest among some of the hospitalized patients with severe clinical myocarditis (Figure 1).

\section{Discussion}

In recent experiments we showed that the $F\left(a b^{\prime}\right)_{2}$ fragments of the $\operatorname{IgG}$ of a patient with chronic Chagas myocarditis complexed the antigen-binding IgG fragment $F\left(a b^{\prime}\right)_{2}$ obtained from infants with documented acute $T$. cruzi parasitemia, and immunecomplex formation was specifically inhibited by sarcolemma membranes derived from L6 clones of striated rat skeletal muscle. ${ }^{13}$

We have demonstrated that $T$. cruzi hemoflagellates bear antigenic complementary surfaceattachment molecules to receptors on L6 myoblast host cells. ${ }^{13}$ In a recent publication we have further clarified that $T$. cruzi plasma membrane, striated muscle sarcolemma recognition involves the specific interaction of paired muscarinic cholinergic and $\beta$-adrenergic receptors of heart muscle cells with parasite attachment sites. ${ }^{14}$ We now propose, therefore, a working hypothesis to explain the interrelation between the formation of anti-sarcolemma, anti-idiotype antibodies and the development of chronic Chagas myocarditis (Figure 2). In the initial infection, parasite-attachment molecules interact through molded tertiary structures of epitopes with complementary receptor sites on the muscle sarcolemma to initiate recognition and parasitosis. Later in the infection, anti-idiotype antibodies downregulate the primary antibody response against the parasite-attachment molecules. ${ }^{28,29}$ In a subset of susceptible subjects, anti-idiotype antibodies are raised in excess, and some react with the mirrorimaged structures of sarcolemma muscarinic cholinergic and $\beta$-adrenergic receptors, thereby inducing myocarditis.

In the investigation reported here, we sought the association of elevated levels of IgG anti-acute $T$. cruzi $\mathrm{F}\left(\mathrm{ab}^{\prime}\right)_{2}$ with anti-sarcolemma activity in chronic Chagas myocarditis. Indeed, the data reported in this investigation showed that hospitalized patients with severe chronic Chagas myocarditis and congestive heart failure have 1) abnormal elevated levels of total IgG anti-acute T. cruzi infection $\mathrm{F}\left(\mathrm{ab}^{\prime}\right)_{2}(87.0 \%, n=23)$ and 2$)$ abnormal levels of complexed anti-idiotype antibodies, which were significantly higher than those measured in asymptomatic $T$. cruzi seropositive subjects of an endemic village $(p<0.001)$. Moreover, the investigation reported here showed that the $\mathrm{cF}\left(\mathrm{ab}^{\prime}\right)_{2}$ antibody fragments of 4 histology-proven, chronic Chagas myocarditis patients specifically complexed $\mathrm{aF}\left(\mathrm{ab}^{\prime}\right)_{2}$ and that this anti-idiotype reaction was significantly blunted by preabsorption of $\mathrm{cF}\left(\mathrm{ab}^{\prime}\right)_{2}$ with PAMs.

A slight rise of levels of IgG anti-acute $T$. cruzi $\mathrm{F}\left(\mathrm{ab}^{\prime}\right)_{2}$ is an expected result from normal antiidiotype network immunoregulation of asymptomatic, chronically infected subjects, however, when 


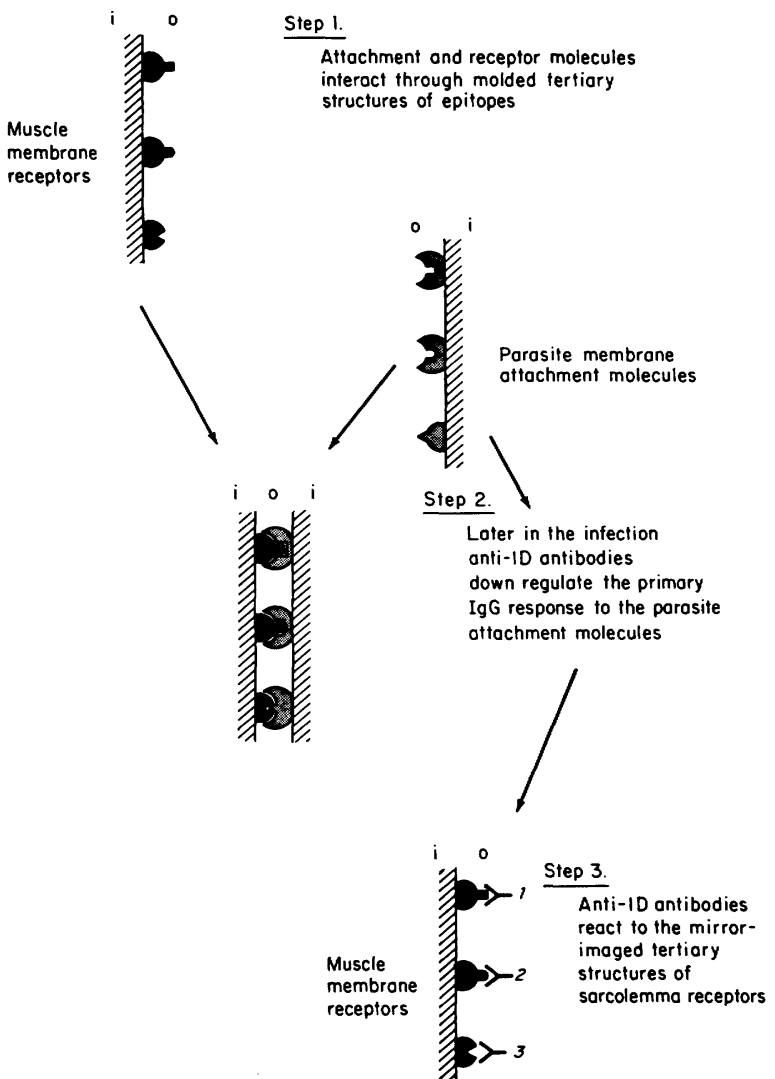

FIGURE 2. Working hypothesis to explain interrelation between anti-idiotypic antibodies and the development of chronic Chagas myocarditis (see "Discussion").

markedly elevated IgG anti-idiotype immunecomplex activity levels were shown among hospitalized patients with chronic Chagas myocarditis, the association to lesion production was made $(t$ distribution, $p<0.001)$. This correlative statistic suggests but does not prove that a pathogenic mechanism may exist between elevated IgG anti-idiotype activity levels and the clinical and pathologic expression of myocarditis. In support of the data reported here is a recent investigation showing that peripheral blood T-cells from patients with the cardiac form of Chagas disease are stimulated to proliferate by monospecific anti-flagellate antibody raising the possibility that these patients have auto-antiidiotypic T-cells. ${ }^{30}$

Two observations merit further discussion. In the study reported here, the median age of patients with chronic Chagas myocarditis was higher by 13 years than the age range of asymptomatic seropositive subjects of the Moniz Ferreira survey study, and it may be argued that the rate of reinfection was different between the two groups of $T$. cruziinfected subjects. Against this proposition is the reasonable likelihood that the hospitalized patients with chronic Chagas myocarditis and the asymptomatic seropositive Moniz Ferreira village subjects had a similar exposure rate to infected Triatoma (Reduviid) insects because both groups probably lived in similar socioeconomic endemic zones near the referral hospital. Furthermore, it is generally accepted that seropositive patients with chronic $T$. cruzi infection have a life-time low-load parasitosis because intracellular pseudocysts of amastigotes are seldom or sparsely found after careful histopathologic examination of hearts with myocarditis and of other target organs ${ }^{31}$ and because parasitemia may be established in only $40 \%$ of seropositive chronically infected patients by the sensitive test of xenodiagnosis. ${ }^{31}$ Therefore, an important pathogenic factor to consider is the interaction of the duration of the infection with a possible genetic predisposition to an abnormal immunoregulatory response to the $T$. cruzi parasitosis.

\section{Acknowledgments}

We are grateful for the technical assistance of Karen I. Hunt. We thank the Public Health Service of the state of Bahia and the many physicians of Bahia, Brazil, who provided the sera for the study. We are grateful to Drs. Mauricio B. Rosenbaum, Pablo Chiale, Amalia Segovia, and Leonor SterinBorda of Argentina for providing us with invaluable sera for this study. We thank Dr. Marc Barr of the Department of Surgery of the Columbia-Presbyterian Hospital Medical Center for providing us with the serum of the human transplant with chronic Chagas myocarditis. We are indebted to Dr. Hugo H. Molina, cardiopathologist of the Ramos Mejia Hospital (Buenos Aires) and Dr. Juan Carlos Felix, pathologist of the New York Hospital-Cornell Medical Center, for the interpretation of the endomyocardial biopsies and the resected heart, respectively.

\section{References}

1. Chagas C: Nova tripanozomiaze humana. Mem Inst Oswaldo Cruz 1909;1:159-218

2. Rothhammer AU, Allison MJ, Nunez L: Chagas disease in pre-Colombian South America. Am J Phys Anthropol 1985; 68:495-498

3. Cunningham DS, Grogl M, Kuhn RE: Suppression of antibody responses in humans infected with Trypanosoma cruzi. Infect Immun 1980;30:496-499

4. Sterin-Borda L, Perez Leiros C, Wald M, Cremaschi G, Borda E: Antibodies to beta ${ }_{1}$ and beta ${ }_{2}$ adrenoceptors in Chagas' disease. Clin Exp Immunol 1989;74:349-354

5. Teixeira ARL, Teixeira G, Macedo V, Prata A: Acquired cell-mediated immunodepression in acute Chagas' disease. $J$ Clin Invest 1978;62:1132-1141

6. Laranja FS, Diaz E, Nobrega G, Miranda A: Chagas disease: A clinical, epidemiologic and pathologic study. Circulation 1956;14:1035-1054

7. Santos-Buch CA, Acosta AM, Zweerink HJ, Sadigursky M, Anderson OF, von Kreuter BF, Brodskyn CI, Sadigursky C, Cody RJ: Primary muscle disease: Definition of a $25-\mathrm{kDa}$ polypeptide myopathic specific Chagas antigen. Clin Immunol Immunopathol 1985;37:344-350

8. Sadigursky M, Acosta AM, Santos-Buch CA: Muscle sarcoplasmic reticulum antigen shared by Trypanosoma cruzi clone. Am J Trop Med Hyg 1982;31:934-941

9. Acosta AM, Sadigursky M, Santos-Buch CA: Anti-striated muscle antibody activity produced by Trypanosoma cruzi. Proc Soc Exp Biol Med 1985;172:364-369 
10. Khoury EL, Diez C, Cossio PM, Arana RM: Heterophile nature of EVI antibody in Trypanosoma cruzi infection. Clin Immunol Immunopathol 1983;27:283-289

11. Szarfman A, Terranova VP, Rennard SI, Foidart JM, FatimaLima M, Scheinman JI, Martin GR: Antibodies to !aminin in Chagas' disease. J Exp Med 1982;155:1161-1169

12. Teixeira ML, Dvorak JA: Trypanosoma cruzi: Histochemical characterization of parasitized skeletal muscle fibers. $J$ Protozol 1985;32:339-343

13. von Kreuter BF, Sadigursky M, Santos-Buch CA: Complementary surface epitopes, myotropic adhesion and active grip in Trypanosoma cruzi-host cell recognition. Mol Biochem Parasitol 1988;30:197-208

14. von Kreuter BF, Santos-Buch CA: Modulation of Trypanosoma cruzi adhesion to host muscle cell membranes by ligands of muscarinic cholinergic and beta adrenergic receptors. Mol Biochem Parasitol 1989;36:41-50

15. Borda E, Pascual J, Cossio PM, de la Vega M, Arana RM, Sterin-Borda L: A circulating IgG in Chagas disease which binds to beta-adrenergic receptors of myocardium and modulates their activity. Clin Exp Immunol 1984;57:679-686

16. Imbach P, d'Apuzzo V, Hirt A: High-dose intravenous gammaglobulin for idiopathic thrombocytopenia purpura in childhood. Lancet 1981;2:1228-1231

17. Oldstone MBA: Prevention of Type I diabetes in nonobese diabetic mice by virus infection. Science 1988;239:500-502

18. Gajdas PH, Outin H, Elkharrat D: High-dose intravenous gammaglobulin for myasthenia gravis. Lancet 1984;1:406-407

19. Roifman CM, Schaffer FM, Wacksmith SE, Murphy G, Gelfand EN: Reversal of chronic polymyositis following intravenous immune serum globulin therapy. JAMA 1988; 258:513-515

20. Newburger JW, Takahashi M, Burns JC: The treatment of Kawasaki syndrome with intravenous gammaglobulin. $N$ Engl J Med 1986;315:341-347
21. Zanetti M, Bigazzi PE: Anti-idiotype immunity and autoimmunity. Eur J Immunol 1981;11:187-195

22. Plotz PH: Autoantibodies are anti-idiotype antibodies to antiviral antibodies. Lancet 1983;2:824-826

23. Huber SA: Viral and immune mechanisms in cardiac diseases, in Spory CJF (ed): Immunology and Molecular Biology of Cardiovascular Diseases. Lancaster, MTP Press Ltd, 1987, pp 143-159

24. McNutt NS, von Kreuter BF, Santos-Buch CA, Hsu A, Felix JC, Reison DS, Barr ML: La piel en la enfermedad de Chagas en un paciente con supresion inmunologica. Patologia $1988 ; 22: 22-25$

25. Weir DM, Herzenberg LA, Blackwell C, Herzenberg LA: Handbook of Experimental Immunology, ed 3. London, Blackwell Scientific, 1978, p 39.10

26. Sadigursky M, Brodskyn CI: A new liquid medium without blood and serum for culture of hemoflagellates. Am J Trop Med Hyg 1986;35:942-944

27. Croxton EF: Elementary Statistics With Applications in Medicine and the Biological Sciences. New York, Dover Publications, Inc, 1959, pp 228-230

28. Jerne NK, Roland J, Cazenave PA: Recurrent idiotypes and internal images. EMBO J 1982;1:243-247

29. Kohler H: Idiotypic network interactions. Immunol Today July $1980 ; 18-21$

30. Gazzinelli RT, Morato MJ, Nunes RME, Cancado JR, Brener Z, Gazzinelli G: Idiotype stimulation of T lymphocytes from Trypanosoma cruzi infected patients. J Immunol 1988;140:3167-3172

31. Santos-Buch CA, Acosta AM: Pathology of Chagas disease, in Tizard I, (ed): Immunology and Pathogenesis of Trypanosomiasis. Boca Raton, Fla, CRC Press, 1985, pp 145-183

KEY WORDS - Trypanosoma cruzi • antibodies • Chagas disease $\cdot$ myocarditis 